\title{
Magda Jeanrenaud, La Traduction, là où tout est pareil et rien n'est semblable, Préface de Claude Hagège, Bucarest, EST-Samuel Tastet Editeur, 2012, 346 p.
}

\author{
Ana-Maria Minuț* \\ Facultatea de Litere, Universitatea „Alexandru Ioan Cuza”, Bd. Carol I 11, 700506 Iași, România
}

Pusă în slujba unei demonstrații de evaluare și critică a traducerii, erudiția Magdei Jeanrenaud face posibilă coroborarea unor elemente diferite, provenind din mai multe tipuri de teorii ale traducerii (tipul funcțional, reprezentat de Hans Vermeer și Katharina Reiss, cel lingvistic, avîndu-i ca exponenţi pe Roman Jakobson, J.P. Vinay, J. Darbelnet, Georges Mounin, J.C. Catford, Bertrand Richet, tipul interpretativ, ilustrat de Marianne Lederer și Danica Seleskovitch, tipul filosofic, practicat de Antoine Berman, Paul Ricoeur sau Jacques Derrida, tipul sociolingvistic, prin Maurice Pergnier), aplicate inspirat la mai multe studii de caz. Rezultă, în fapt, nu una, ci mai multe demonstrații, căci autoarea are în vedere cinci cazuri de traducere sau de autotraducere (Vasile Alecsandri, I.L. Caragiale, Panait Istrati, Mihail Sebastian şi Emil Cioran). În afara acestor cinci evaluări de prim plan, există, încă din secțiunea Avant-propos, situată după prestigioasa prefață a lui Claude Hagège, şi numeroase alte evaluări colaterale, prilejuite, printre altele, de referirile inevitabile la principiul fidelităţii în traducere, la ,ameninţarea” intraductibilității sau la trimiterile intertextuale; acestea vizează diverse cazuri punctuale, reprezentate fie de soluțiile traductive propuse, în versiunile românești, pentru anumite titluri, sintagme, cuvinte din lucrările lui Tzvetan Todorov sau Amélie Nothomb, fie de problemele pe care le ridică traducerea, din franceză în germană (sau în română), a unei caricaturi din domeniul sportiv în care în original se mizează pe polisemia lui but.

Capitolul intitulat Traducteur - auteur: une relation décalée pleacă de la consecințele antrenate de negarea sau minimalizarea, în studiile de teorie literară de sorginte structuralistă, din anii 70 ai secolului trecut, a intenționalității autorului și a supremației instanței auctoriale. Dacă cititorului i se acordă libertatea de a interpreta textul în mod independent de intențiile autorului, de această libertate beneficiază, în mod evident, și traducătorul („le Lecteur par excellence”), eliberat de canonul supunerii fără rezerve în fața intențiilor scriitorului.

Chiar dacă, așa cum au demonstrat importante studii de teorie literară, intenționalitatea s-a dovedit imposibil de expulzat, căci însuşi criteriul coerenței, esențial pentru adecvarea și valoarea unei interpretări, nu poate fi conceput fără recursul la premisa sau probabilitatea unei intenții (p. 35), sînt evidențiate mai multe beneficii, teoretice și practice, ale abordărilor care au vizat autonomizarea actului traducerii. În plan teoretic, autoarea menționează diversificarea perspectivelor referitoare la traducere, precum cele de tip interpretativ sau comunicațional. Dintre teoriile care au relativizat rolul pe care-l ocupă intenționalitatea autorului în actul de traducere, o atenție aparte este acordată, pe de o parte, așa-numitei teorii a polisistemului (extrem de utilă în economia lucrării, anticipînd unele aspecte tratate în capitolele următoare), a lui Gideon Toury, care acordă traducerii acelaşi statut precum operei originale; pe de altă parte, teoria elaborată de H.J. Vermeer şi Katharina Reiss (așa-numita Skopostheorie) deplasează accentul asupra statutului textului, determinant în alegerea metodei și a strategiei de traducere. Cît despre avantajele de ordin practic, sînt evidențiate cele constînd în depășirea unor analize sterile, de tip contrastiv, preocupate cu obstinație de identificarea devierilor şi a diferențelor (adesea, de „expresivitate”) dintre textul-țintă și textul-sursă.

Cum cunoașterea varietăţilor culturale care stau la baza unui text contează extrem de mult în procesul traducerii, care nu poate face abstracție de contexul socio-cultural și de relația unei culturi cu limba sa maternă, cartea conține o secțiune consistentă, intitulată Francophonie, bilinguisme et traduction, care tratează profilul influențelor franceze exercitate (mai întîi, prin intermediar grecesc și rusesc și apoi în

*Adresă de corespondență: a_minut@hotmail.com. 
mod direct) în spațiul cultural românesc și căile lor de manifestare. În condițiile în care francezei i se acordă, pe drept cuvint, rolul cel mai important în modernizarea culturii și a limbii române, autoarea oferă, sprijinindu-se predominant pe bine-cunoscuta lucrare a lui Pompiliu Eliade (apărută într-o vreme în care influența franceză era în plină desfăşurare)— De l'influence française sur l'esprit public en Roumanie. Les origines. Étude sur l'état de la société roumaine à l'époque des règnes phanariotes, Ernest Leroux, Libraire-Éditeur, Paris, 1898-o descriere a celor mai importante momente din istoria relațiilor româno-franceze, care au determinat o schimbare decisivă de Weltanschauung și, în plan lingvistic, o modernizare masivă și extrem de benefică a lexicului românesc.

Dacă, după formula lui Paul Zarifopol, cu Franța a început „mișcarea de dezmojicire” (Pentru arta literară, II, ediție îngrijită de Al. Săndulescu, Editura Minerva, București, 1971), de bună seamă că personajul Chirița al lui Alecsandri ilustrează prima fază a procesului. Idiolectul ei ridicol este analizat prin prisma procedeelor "tehnice” ale traducerii, descrise de Vinay și Darbelnet, a celor trei tipuri de traducere identificate de J.-C. Catford și cu ajutorul conceptului de transcodaj, așa cum l-a definit Maurice Pergnier (cu privire la modalitatea de transpunere a idiotismelor). Emanciparea, după Werner Koller (Einführung in die Ubersetzungswissenschaft, UTB, Stuttgart, 2011), este o formă de critică culturală, care are și o dimensiune lingvistică, iar frenezia imitativă și traductivă reprezintă contribuția adusă „emancipării” de tipul de personaj semidoct ironizat de Alecsandri.

În ceea ce privește transpunerea lui Caragiale în franceză, după abordarea mai multor aspecte importante în procesul evaluării traducerii (profilul traducătorilor-Eugène Ionesco și Monica Lovinescu, limitele dintre traducerea şi adaptarea unui text dramatic, starea limbii române în prima jumătate a secolului al XIX-lea), atenția se îndreaptă asupra unor aspecte punctuale, referitoare la traducerea didascaliilor, a repetițiilor și a clișeelor, a referințelor culturale, a numelor proprii (inclusiv a poreclelor) și a formulelor afective de adresare, a interjecțiilor și a punctuației. Principalele probleme sînt identificate, pe de o parte, în modalitatea de redare a franțuzismelor din textul original și, pe de altă parte, în normalizarea, ordonarea, raționalizarea a ceea ce în vorbirea perso- najelor lui Caragiale trădează, dimpotrivă, confuzie, dezordine, derivă, deriziune sau expansivitate.

În cazul textelor lui Panait Istrati, au fost reținute practicile traductive a căror frecvență le conferă statutul de indici de intenționalitate a autotraducerii din franceză în română; procedeele utilizate se încadrează preponderent în categoria celor „oblice” în terminologia lui Vinay și Dabelnet, cu efect de restructurare în profunzime a semnificației textuluisursă. Exemplele extrase din versiunile românești ale operelor Oncle Anghel, La Maison Thüringer și Tsatsa Minnka dovedesc o explicitare și o nuanțare evidentă a descrierilor, o schimbare a perspectivei naratologice (vocea naratorului devenind mult mai puternică), o reorganizare a textului original inclusiv prin redistribuirea paragrafelor, ca și o prefacere a registrului standard și neutru din original în registru oral, familiar, dialectal sau afectiv.

Versiunea în limba franceză a romanului Accidentul al lui Mihail Sebastian, datorată lui Alain Paruit, face obiectul unei atente evaluri din perspectiva „universaliilor” (uniformizare, omogenizare, raționalizare, clarificare, explicitare, „înnobilare”) care se manifestă în actul propriu-zis al traducerii. Efectele constau în restructurarea considerabilă a unor paragrafe, modificarea întrebuințării ghilimelelor (cel mai frecvent, prin suprimarea lor, atunci cînd acestea marchează intervenția, în discursul primar, a unui discurs secundar), eliminarea unor detalii ,inutile”, „stilizarea” unor pasaje, evitarea repetițiilor (chiar și atunci cînd acestea au încărcătură simbolică, aşa cum e cazul repetării cuvîntului ceață, devenit, în franceză, cînd brume, cînd brouillard), dezambiguizarea a ceea ce voit imprecis etc. Virajul progresiv și deliberat al traducătorului spre tiparul realist își găsește explicația, conform autoarei, în dorința (mai cu seamă a editorilor) de a evita receptarea Accidentului, de către un public francez excedat de epigonii lui Marcel Proust, în cheie proustiană.

În ceea ce privește versiunea în franceză a operelor românești ale lui Cioran, modificările importante (constînd în special în omisiuni) faţă de textul-sursă sînt considerate rezultatul unor reticențe ideologice şi estetice (ale autorului însuși, traducătorului, editorului). Grație acestor treceri sub tăcere, imaginea consacrată a lui Cioran este pusă la adăpost de derapajele ideologice sau imperfecțiunile stilistice ale tinereții.

Multe din precizările teoretice diseminate pe par- 
cursul capitolelor justifică inspirata algere a subtitlului là où tout est pareil et rien n'est semblable, împrumutat dintr-una din lucrările filosofului şi eseistului André Glucksmann (Le Bien et le Mal. Lettres immorales d'Allemagne et de France, Hachette, Paris, 1997), circumscrisă unui cu totul alt domeniu. În jocul dintre tout est pareil și rien n'est semblable intră mai mulți factori: decalajele (de interiorizare a intenției autorului, de orizont de aşteptare etc.) existente în relația autor - traducător, curajul traducătorului de a apela, atunci cînd simpla transpunere dintr-o limbă în alta nu pare suficientă, la o „a treia limbă a traducerii" (capabilă să recupereze pierderile și să transmită alteritatea textului străin) sau dozajul aşanumitelor „universalii” ale traducerii.

Erudită și subtilă, bazată pe o bogată experiență de traducător, cartea Magdei Jeanrenaud este o pledoarie pe deplin convingătoare a necesității traducerii de a reflecta asupra ei înseși. 